\title{
Tourist guide reflections on the spatialities of mass tourism: A case study of Finnish package tourism in Crete
}

\author{
VILHELMIINA EMILIA VAINIKKA
}

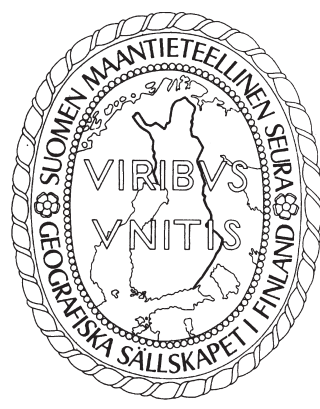

Vainikka, Vilhelmiina (2016). Tourist guide reflections on the spatialities of mass tourism: A case study of Finnish package tourism in Crete. Fennia 194: 1, pp. 64-78. ISSN 1798-5617.

The mass tourism destination is a well-known spatial category for large-scale tourism practices. However, little critical attention has been paid to the construction of the category itself in relation to the spatialities of different social groups. This study scrutinizes the situated spatial relationships within mass tourism in a flexibly conceptualized mass tourism destination. Social constructionist methodology and different place theories are utilized in order to analyze tourist guides' reflections of Finnish mass tourism in Crete. The positionality of the guides to mass tourism spatialities was tested with a twofold interview agenda: asking the guides to evaluate their own spatialities and those of their clients. Drawing parallels between the mass tourism destination and the seaside resort are not straightforwardly supported in these interviews. The daily movement of the guides, their destination knowledge or discussions about the destination and their leisure-time activities all shape their relationship with the destination and produce spatialities that are evaluated in relation to their clients' spatialities. The guides construct two ideas of spatiality of mass tourism, intensive and extensive, through which spatialities are interpreted at an ideological and practical level. These spatial constructions reflect the hybrid character of the contemporary mass tourism and contextualize the mass tourism destination as different combinations of situated spatial experiences. Based on the results the academic research should utilize different user perspectives to the theorization of mass tourism destination.

Keywords: mass tourism destination, social construction, tourist guides, place, Crete, Finland

Vilhelmiina Vainikka, Department of Geography, University of Oulu, P.O. Box 3000, 90014 University of Oulu, Finland. E-mail: vilhelmiina.vainikka@oulu.fi

\section{Introduction}

Tourism has been a fast growing phenomenon for decades. Mass tourism has formed the core of this growth. Advances in transport in the 1950s and 1960s and increased free-time for the middle class multiplied the ways holidays could be spent abroad and promoted the democratization of large-scale aviation-based tourism (Löfgren 1999). Package tours were developed, especially in Europe, to accommodate the rapid growth in demand and provide trips at lower prices (Rosselló \& Riera 2012). In Finland too, the beginning of airbased outbound tourism for the masses took the form of charter package tours in the late 1960s (Selänniemi 2001). Along with the growth in tour- ist experiences, transforming cultural values and advances in information technology, the masses are more scattered than ever before. The conceptualization of mass tourism as a category for analysis (cf. Brubaker \& Cooper 2000) has led to different interpretations of the current changes. Some perceive mass tourism as being in decline and being replaced by "new tourism" (Poon 1993) or as growing only because of new markets (Shaw \& Williams 2002), while others state that mass tourism is in fact transforming into a form of global 'mega-tourism' (Wheeller 2003). Mass tourism itself is seen as changing (Torres 2002; Bramwell 2004). Tourism categories are blurring as a result of product diversification (Duval 2004). More recently low-cost carriers and Internet booking sys- 
tems (Casey 2010; Rosselló \& Riera 2012) have challenged the idea of mass tourism founded on charter-based package tours and diversified its destination network. The package tours themselves have changed over the years and are not as rigidly packaged anymore: tourists can make their own decisions on how to use their time and choose from a variety of options (Torres 2002; Aquiló et al. 2005; Räikkönen \& Honkanen 2013). Also in Finland low-cost carriers and otherwise improved airline connections to Central Europe and Asia have made possible large tourist flows to large numbers of destinations (Finavia 2014), but package tours continue to be one central part of Finnish outbound tourism and its imagery. Package tours are the focus in this study as a stereotypical but changing form of mass tourism, as well as being a large and democratized tourism phenomenon. In this sense, this is not a study of Finnish mass tourism overall, but a part of Finnish mass tourism.

The need to rethink the categorization of mass tourism has received surprisingly tangential interest from researchers in tourism and human geography (Vainikka 2013). Mass tourism has been used both as a category of analysis in research and as an everyday category of practice among industry professionals and in the general discourses amongst people. As long as there has been mass tourism, there has also existed some degree of critique towards it within research and in general discourse by the elite whose privilege to travel has been under threat, resulting in "tired stereotypes that set 'the real traveler' against the turistus vulgaris" (Löfgren 1999: 8). To step back from the simplified hierarchical notions of mass tourism that foster partial academic knowledge on the phenomenon, more emphasis should be placed on the relationship between the different users and the product (such as the destination) in question (Miller 1987). Michel Maffesoli (1996, see also Obrador 2012) claims that today's masses are not a homogeneous entity but rather such culture should be conceptualized as separate, fragmented neo-tribal groupings based on tastes and lifestyles which people move between and identify themselves with. Contemporary mass tourism can consist of different forms of 'tourisms' even within mass package tourism representing diverse motivations (see Jacobsen et al. 2014).

The key argument in this paper is that as spatial categories, mass tourism destinations are never separate of human experience. The way such categories, analytical or practical, are constructed, draw from situated knowledges (Rose 1997) and are relational to those who construct them. In this case, a social group of guides is of interest and how its members are socialized into the practices of the field to produce and interpret their knowledge on mass tourism. By letting tourist guides evaluate both their own relationship with the place and how they see their clients' spatial practices, the twofold positionality to mass culture can be addressed. The chosen approach recognizes historically bound interpretations (McCabe 2005) and considers contextuality as a "reflexively constituted relationship" (McCabe \& Stokoe 2004: 606). The research questions are: How do guides interpret mass tourism and its spatiality? How do guides describe their own spatiality in relation to that of their clients? Spatialities refer to different connections that people have with places, not only material but also meanings and emotions.

The theories of place help to address the category of mass tourism destination analytically. They also help to conceptualize how the established international agglomerations of tourism or homes for global tourism are not only the resort-areas but are relational to other activities outside their imagined bounds and unfold into what other scholars might categorize as "alternative tourism". The mass tourism flow from Finland to Crete is analysed as "mass tourism" regardless of how many different spatialities ('destinations') it might represent.

Local guides have been researched in tourism studies to some extent (Gmelch 2003; Jokinen \& Veijola 2008; Rantala 2010), but in this case the guides interviewed represent the expatriates of their clients' (tourists') main country of origin as the tour operator reps in Andrews' work (2011). The guides' role in interpreting the phenomenon is professional, but they also have personal roles such as being a tourist and seasonal inhabitant at the destination. Their talk of the phenomenon as representatives of an institutional social group in an interview situation is not neutral, but a part of the process of identity construction and differentiation, something they cognitively intend to represent (McCabe 2005). They are likely to formulate meanings based on their (both personal and professional) identity, values or attitudes in relation to wider cultural discourses on travelling and holidaying, and reveal how they create their knowledge in relation to dominant cultural ideologies (McCabe 2005) and memberships of different groups (Obrador 2012). Guides are insiders of mass tourism because they are working within the 
phenomenon, but still outsiders to other tourists' experiences or locals' viewpoints. In a cultural sense, their viewpoint is closer to that of the tourists' and they are able to better understand clients' cultural context. Guides' contribution brings valuable knowledge from the industry to the partial canon of academic knowledge (see Tribe 2006) by offering a context outside research in which the knowledge on spatialities and its limits can be addressed. Their job is to observe, evaluate and sense the phenomenon, places, and their clients' needs by looking, discussing and hearing (see Cheong \& Miller 2000). Therefore, their views on mass tourism spatialities are based on large numbers of discussions with their clients, who they cannot choose. They also contribute to their clients' spatial relationship with their suggestions and help.

This paper is organized in the following sections. First, I will present the theoretical discussion about the relationships between mass tourism and the place that this study concentrates on. Second, I will introduce the methodology, methods and the case study area of Crete. The analysis section is divided into three parts. The first one concentrates on analysing the working role of the guides based on interview material. The second part addresses the different spatialities of the guides based on mental maps and interviews on their physical movements, place-based knowledge and leisuretime activities. The third section introduces the ideas of intensive and extensive spatiality in relation to mass tourism, based on the guides' views on both their own spatiality and that of their clients. At the end, a discussion is provided and implications for further research are highlighted.

\section{Conceptualizations of a mass tourism destination as a place}

The concept of a mass tourism destination brings tourism studies and geography into dialogue around the concept of place in many ways. Different spatial theories can be utilized simultaneously to conceptualize mass tourism and a mass tourism destination.

Firstly, mass tourism destinations have been conceptualized as the result of large-scale capitalist-oriented tourism developments: material, bounded space, or even in some cases an administrative unit (e.g. Butler 1980). The stereotypical mass tourism settings and purpose-built seaside resorts are highly specialized from the neighbouring areas with similarities to other destinations but this does not mean that they are identical in their development or functions (e.g. Aguiló et al. 2005; Ivars i Baidal et al. 2013). In the traditions of sustainability, industry, destination management and development studies (Brey et al. 2007; Saraniemi \& Kylänen 2011) a mass tourism destination is understood as being a developed, governed and marketed entity (Ashworth \& Voogd 1990) where there is an aim of improving visitor satisfaction or controlling impacts. Tourists thus literally consume these spaces (see Urry \& Larsen 2011) and influence their transformation under the control of tour operators (e.g. Turner \& Ash 1975; Krippendorf 1987). Reducing mass tourism into certain locales, resorts or sights, explained by their material qualities, ignores the individual wanderings outside these mass spaces and the diverse contexts and ways in which these places are consumed and produced. It has to be acknowledged that destinations can be perceived on many different scales; they may be a country, city or even a tourism product (Saarinen 2004).

Secondly, the mass tourism destination category is socially constructed by attaching meanings to places (Squire 1998; Young 1999; Saarinen 2004) and symbolically consumed (Urry \& Larsen 2011). People categorize the same physical entities as particular types of places alongside identifying themselves as particular types of category members (McCabe \& Stokoe 2004: 604). Tourist guides, or any other people, are members of society and culture, influenced by different discourses that affect their identity and choice-making. Places, conceptualized as social constructions, are negotiated (Jackson 1989) and a part of the judgment of taste (Bourdieu 1984; Löfgren 1999). They are also sources and results of belonging (Vainikka 2012). The label "mass tourism destination" can thus be seen as a symbol of 'destruction' or popularity. Similarly for some researchers the concept of mass tourism destination has been a category that exemplifies the loss of authenticity (e.g. Boorstin 1964; Turner \& Ash 1975; Relph 1976; Poon 1993), but for some the complexities of the category itself is interesting (e.g. Miller \& Auyong 1998; Obrador Pons et al. 2009; Anton Clavé 2012). This is an important level in understanding places of mass tourism, because places are produced through hierarchical categorizations that have material effects. In this sense, it is not only significant what is described and how something is 
told but also in what context and when. Edward Relph wrote an influential book in 1976 on placelessness that became a popular framework for the judgment of any place that has been considered to have lost its authenticity. He later (Relph 2000) commented on his own work and acknowledged that the world back then was very different from today and that the thesis of placelessness was situated in that framework. Nowadays each place should "be assessed carefully on its own terms" (ibid.: 618). In a similar fashion, Dan Knox (2009: 146) argues:

"Certainly, we could argue that the Spanish coastline has become relatively unattractive in relation to an idealized notion of pristine nature, but' [...] 'without understanding what motivates people to continue to visit such apparently unattractive places. It may well be that such places have an attraction that tourist studies have thus far failed to grasp in any meaningful sense."

The previous quotation suggests that the different positions of tourists and researchers to address the destination have led to conflicting interpretations and urges for more in situ interpretations that make better use of different individual and social perspectives.

Thirdly, a mass tourism destination can be considered in terms of relational space: places of flows and encounters that are embodied, sensed, practised and performed. These places are simultaneously produced and consumed by tourists, (local) workers, tourism professionals and the encounters between them (Edensor 2001; Sheller \& Urry 2004; Urry \& Larsen 2011). This approach highlights that places are never ready, but in the process of making and in connections with other places (Massey 2005; Agarwal 2012), such as the homes of tourists and other destinations. The active role of different people in both the construction and consumption of a tourist place, and the intertwined character of it is embodied, cognitive and affective (Rakić \& Chambers 2012). Contemporary people are becoming increasingly mobile in their everyday lives and more connected through social networks that have a role in creating tourism (e.g. Larsen et al. 2007), but different social groups and individuals are situated in distinct ways with regard to these flows (Massey 1994, 2005) of tourism. The framing of the so called mobile class has though been criticized, because the research is mainly conducted by members of that same group itself, i.e. western academ- ics and journalists (Massey 1994). It also excludes or passivizes anything that is left outside it, not taking into consideration that they are relations that produce (im)mobilization, not characteristics of the objects, such as the local resident or the tourist (Franquesa 2011). In mass tourism, in particular, it is important to address the complexity of the phenomenon because it represents the democratization of international travelling in different situated relations. Some researchers have already applied relational thinking to mass tourism destinations (Obrador Pons et al. 2009), as urban structures that are accumulations of innovations in the form of leisure, lifestyle-related mobility (Anton Clavé 2012) or its effects on the restructuring of coastal resorts (Agarwal 2012) and in relation to mobile practices in youth tourism (Knox 2009). Mass tourism destination is thus continuously produced in different relations.

Influenced by Hägerstrandian time-geography "the destination" can be thought of as an accumulation of all those places and paths that one visits (as a guide or tourist) and takes during the trip, meaning that each person has her/his unique assemblage of that destination (Pred 1984; see also Hottola 2005, 2013). In this way, a tourist or guide or any other person does not only consume and produce the resort but also creates places that "can be conceptualized as cumulative archives of personal experience emerging from unique webs of situated life episodes" (Paasi 2002: 807; cf. Vainikka 2012). Paths are ways tourists or guides move in space and time in a given period of time and this movement occurs within social structures that provide the context for objects and humans in the place (see Pred 1984). Compared to the physical transformations of the destination this notion acknowledges the momentary (yet accumulative and contextual) character of place construction. At a collective level these different paths and nodes create different versions of a mass tourism destination that does not necessarily have clear boundaries.

\section{Methodology, material and case study area}

The spatial category of mass tourism destination is not neutral or natural, but it is created in culturally and socially situated discursive practices in a specific moment of time (see Berger \& Luckmann 
1967; Burr 1995). Language and intersubjective discursive practices construct the reality, but the material world and social relations are also active in shaping the ways of seeing it. In the interview situation, the guides project themselves and their knowledge as they seem appropriate while possibly playing down other practices or people (see McCabe 2005). Their talk is "culturally embedded, flexibly deployed and ideological" (ibid.: 87).

Semi-structural interviews were conducted in May 2013 in Crete and took place in a quiet hotel room. The voluntary interviews were recorded and transcribed. Ten participated guides represent the two largest tour operators in Finland: seven from Finnmatkat (TUI group) and three from Aurinkomatkat-Suntours (Finnair group), but the analysis does not separate them by company. The interviews included several questions about the guides' experiences of spatiality, their relationship with their work and the destination, and the spatialities of their clients. The interviewer also asked them to draw mental maps (Gold \& White1974) of areas they see representing their daily physical movement, destination discussions with clients or the knowledge needed of them and their own leisure-time activities.

After going through the contexts of the guides and the mental maps, a more rigorous discourse analysis was applied following the steps outlined by Tuffin and Howard (2001) to the whole material and looked for similarities and differences between and within interviews, in addition to the functions of the language and ideas that were constructed. Several rounds of close-reading of this material were conducted by asking the question: How do the guides articulate mass tourism's spatiality?

Crete is the largest island and the most popular destination outside Athens in Greece (e.g. Apostolakis 2013). It has a population of 600,000. Crete's historical legacy has contributed to European civilization and to the idea of Europe. With mass tourism, Crete is a meeting point for the European cultures of tourism. Crete was chosen as the mass tourism destination of this study because it has been a long established destination for Finnish mass charter package tourism. It has offered places for relaxation, culinary experiences, culture, heritage and activities of many kinds. It is known amongst other things as a family destination and a popular repeat visit destination. Charter flights have been the only direct route and are of a seasonal character between Finland and Crete. Crete is the largest package tour destination for Finns in
Greece with its several resorts (e.g. in the Chania region, Paleochora, Agios Nikolaos, Hersonissos) and the country itself is the second largest destination for Finnish package tours. In 2013, more than 172,000 Finnish charter package tour passengers out of a total of the 938,000 visited Greece (AFTA 2014).

The resort area near the third largest city of Crete, Chania, on the North-West coast is the focus in this study as it is a central tourist area from a Finnish perspective. It was also chosen because the area has several village-resorts close together along the coastal road such as Platanias, Agia Marina, Gerani, Maleme, Agii Apostoli and Kato Stalos. This setting inspires to rethink the concept of a destination more flexibly and the study considers the scales that guides preferred. A spatial separation is not made between different spatial preferences, as has been made in some previous studies that have treated coastal tourists as a category representing certain motivations other than those visiting other areas (e.g. Andriotis 2011).

\section{The guides' contexts}

The interviewed tourist guides were young, most of them under or 25 years old and had worked as guides from a couple of months to a couple of years. This is a bias of the material but also reflexive of the typical guide career that is short due to the year-round seasonal character. The following discussion concentrates on the ways that guides make sense of their personal relationship with their work and mass tourism.

The guides work under different job descriptions: three worked in theme hotels, three in more management-oriented positions, two had an online role and two worked as basic service guides. There is not just "one guide role" but rather different versions of it exist in terms of their tasks and responsibilities. Some of them have multiple responsibilities varying from handling transfers to welcoming receptions, service hours at hotels or excursions in different 'servicescapes' (Bitner 1992). The guide role is in this context to a lesser extent group leading and more about being available in time and space for possible contacts with customers (cf. Edensor 2001; Rantala 2010; see Räikkönen \& Honkanen 2013).

The role of the guide is not described to be a static one, but it is affected by changes in tourism and society, just as tourism itself is changing. Their spatiality has been extended to the virtual world, 
which affects their physical mobility: "Nowadays there are many things you can check instantly on the Internet instead of driving to Rethymno to check it out" (Interview 6). The development of online services has made it possible for their clients to be in contact with the guide already from home before the trip. In addition, the guide's role includes reporting and background information gathering for pre-trip use. The virtual world is considered both as a tool and as a 'servicescape'.

It is not straightforward for the guides to 'know' about their clients' practices. The guides evaluated that, thanks to the better access to destination and travel information online, many clients satisfy their growing interest for such information and actually do 'independently' tasks that previously were the responsibility of the guides, such as informationsearching and help during the trip. The guides also feel that in a mass tourism destination the number of clients is so large, that it limits their knowledge of them. One guide exemplifies: "A mass crowd, so that you are not able to make as close contact as in smaller destinations, where there are fewer clients and you spend more time with them" (Interview 8). This reflects the "mass effect" resulting in regarding the mass as being rather distant due to the high numbers of clients. However, guides name groups of people for whom they continue to be important and who might therefore be highlighted in their 'knowledge': those who do not have time to plan their vacations or gather information themselves, and those who do not have the necessary online skills or trust in them, or who are first-timers at the destination or those who appreciate face-to-face conversations. In fact, some repeater tourists are seen as important informants to the guides.

All the interviewed guides are working in the same destination region, but their relationship to it has been and is different. Most of them had spent a relatively short time on Crete, some months (less than a year), either during one or two seasons, and only two had several years of experience. Only three guides had visited Crete on their own holiday before working as a guide, so their views are heavily situated in a working context. Some of the guides had applied for Crete either because they liked the island or they wanted to get to know it, but some had wished to go somewhere else and they were appointed there instead.

Crete is a meaningful, known place in the mass tourism or package tour destination network, and Finns have an established and dynamic relationship with it. It is common to know someone who has been to Crete, possibly several times and has talked about it. As Pau Obrador Pons et al. (2009) stated, mass tourism destinations are already present in everyday life in the countries of origin and return there, for example, in the form of postcards creating an ongoing process and relationship. There are wider public discourses (McCabe 2005) in Finland that the guides have identified with or not, and shared with their friends, but their own experiences have altered their views of the island. Their image might have covered the whole island even though it may only be based on certain features of resorts:

"[...] this is not nearly as touristic as I had thought, that is, there is plenty of local life here" (Interview $4)$.

"[...] I thought that it must be really boring here because this is not known among young people as a party place[...] I noticed that there is plenty of life here, maybe even more than on Rhodes " (Interview1).

"Well, I had heard a lot of good things and my exboyfriends' mother is crazy about this island of Crete" (Interview 6).

Destinations have both national and more intimate collective levels of meaning that are in other words scalable. The guides often prefer to talk about Crete as an island because that scale seems to better fit to their ideas than specific resorts do.

\section{Spatialities of guides based on mental maps and interviews}

For the guides, their movement and being-in-place happens to a great extent within the limits of their work and the different tasks result in different kinds of 'destinations' in terms of experiences and knowledge: "I have done different work tasks in each destination so I have seen them a bit differently" (Interview 3). The guides drew mental maps to exemplify the area ('servicescape' in Bitner 1992) in which their daily physical movement is mostly done. These 'destinations' do not necessarily correspond with a resort as bounded territory and are dynamically adjusted. The first of two mental maps is drawn by a guide working at a themed hotel, demarcating a very restricted spatiality in her daily movement, see Figure 1a: "Now I just have to do this because... it is Gerani where that Blue Village 


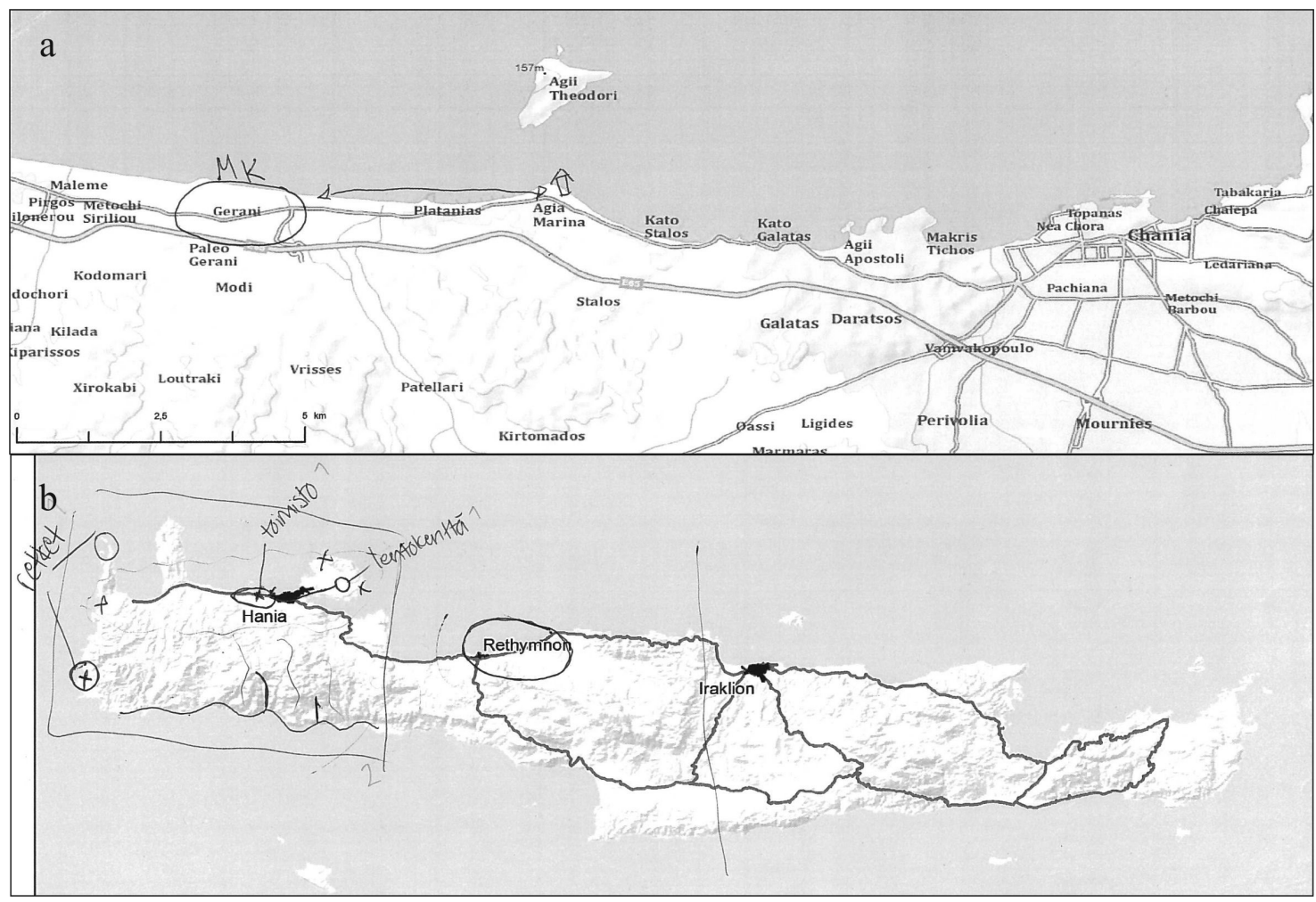

Fig. 1. Two mental maps representing the area for daily physical movement. (Interviews 5 and 1)

is located and we do not move anywhere away from that hotel" (Interview 5). She also mentions that within the drawn area, there are different places that they work in depending on whether they are at the service desk or engaging in activities. The other guide has a more varied job description and she drew a more scattered and larger area representing her daily movements, but more restricted than the area of her discussions (bigger circle), see Figure $1 \mathrm{~b}$. The airport, office and locales visited during excursions are highlighted in this version as places she moves between and in her talk she adds hotels. The dynamic character of being and moving in place is reflected here as a continuous making of the destination (see Pred 1984) and "constructed out of a particular constellation of social relations, meeting and weaving together at a particular locus" (Massey 1994: 154).

The second set of maps (Fig. 2) represents the areas that the guides consider central in their daily discussions with their clients: what they are asked about and what they feel they need to know about. The construction of the mass tourism destination is possible through language without simultaneously being there. The spatiality in this theme is extended beyond their own physical movement as the area covered in discussions is larger, covering almost the whole of Western Crete: working simultaneously on two spatial scales. The 'servicescape' is thus widened to a mental level. The two examples provided include places outside the resort area. The first one is drawn in a more scattered style highlighting specific areas of interest for her clients even though they are staying at the theme hotel, see Figure 2 a. Whereas the other one is drawn by an online guide, working from an office, whose clients may be located in many parts of the island and asking about different areas, see Figure $2 \mathrm{~b}$. She drew a more unanimous larger area, although in the interview, some places and paths are highlighted more than the others. These areas include paths and places which clients ask about: e.g. where to visit and how to get there? 


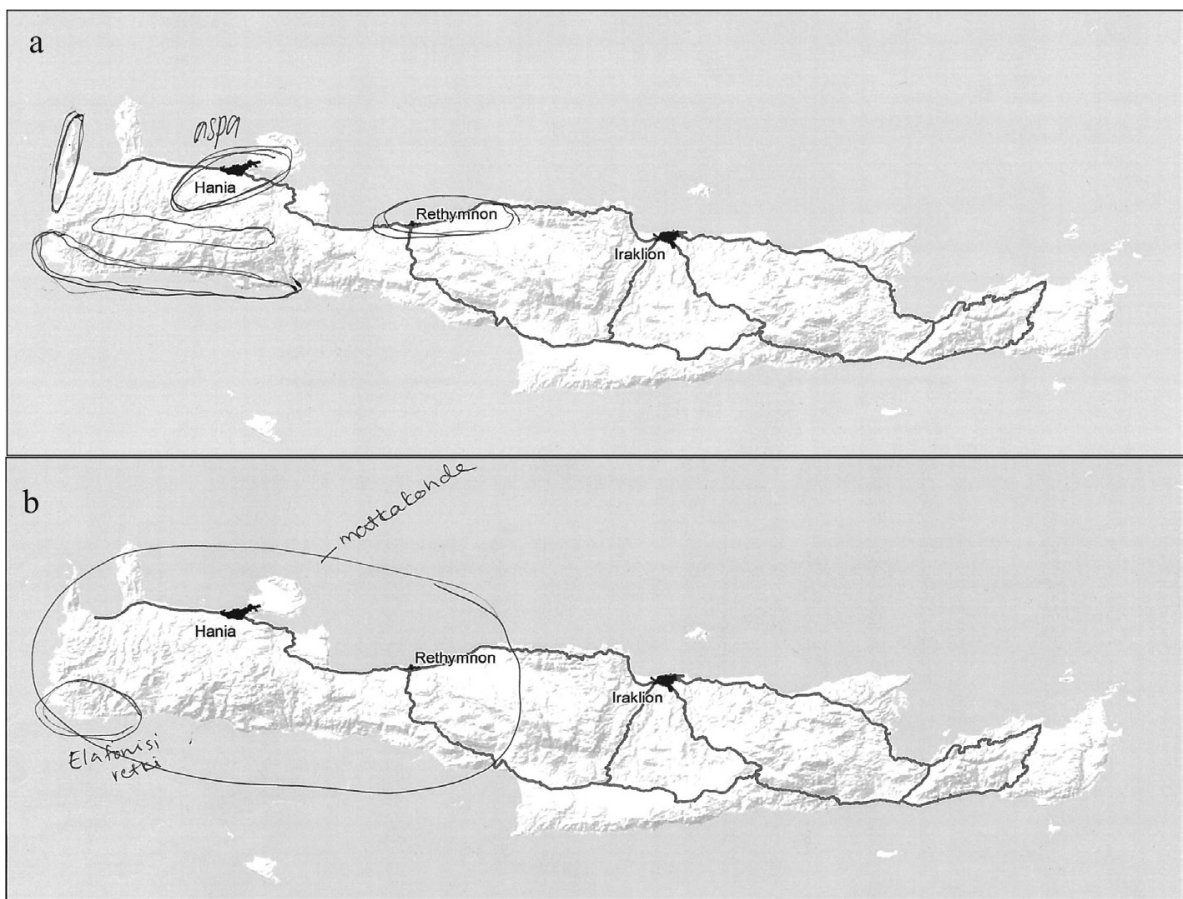

Fig. 2. Two mental maps representing the area covered in discussions. (Interviews 4 and 2)
This talk is marked by the dynamic interaction and relationship between the guides and their clients. The clientele is said to be different in different parts of the season which adds to this dynamicity. An older guide sees a long term change: "Previously you had to take them into a minimarket holding hands, but nowadays it is clear already that they want to know more thoroughly about things" (Interview 9). The spatiality of the guides' knowledge is relational to their clients' needs, interests and questions and they feel they cannot control it totally (see Wright 2002), although the guides talk also exemplifies the use of their own ideological frameworks in describing places: "I almost try to say to everyone that they should go somewhere else... because it [Agia Marina] is a very touristic area" (Interview 1). The knowledge needed about the place is in relation to tourists as members of groups (see Obrador 2012): "Families with children ask what could they do or where could they go with them [...] couples ask where they could go with a rented car [...] some older people might have questions like is there still that thing that used to be here ten years ago" (Interview 3 ). This generalizing excerpt exemplifies ways the guides highlight different phases of life as marking different ways to ask about as well as consume and produce (make) those places which indicates that there are not two identical trips or experiences of a place (see Pred 1984; Paasi 2002).

\section{Construction of "parallax spatiality"}

The guides construct an idea of "parallax spatiality", that is, a relation between their positionality and those of their clients (tourists'). Although both have 'travelled' to the same location, the guides have applied for working (there) as a guide and practise that profession by spending their seasonally organized everyday life in the same place their clients have come for a short holiday (Crick 1989; Gmelch 2003). Both positions are products of these processes and dialogue between mobility and stillness (see Franquesa 2011; Lagerqvist 2013). "If you are here as a worker, there is not much more to do or see after visiting the sights but the basic life works very well here" (Interview 7). "Parallax spatiality" is also something that the guides feel that their clients expect of them in terms of knowledge and professionalism: they assume that the guides have been at the destination longer than them and know everything about the 
place at once, although this is not necessarily the case: "We didn't move away much at all then [on holiday]... now I have toured a whole lot" (Interview 5). As already noted, the length of time spent on the island might be very different in the case of a new guide or a repeat tourist'.

It has to be acknowledged that a holiday is a flexible concept in its own right as the boundaries between work and leisure have become more blurred and also because growing numbers of retired tourists do not necessarily fit into the categorical divide. However, the separation between work and holiday is consistently present in the guides' talk as a relevant context for the phenomenon marking time as a resource. For guides, their own holiday mobility is directed towards Finland, where their clients lead their everyday lives. The relationship to the home country and culture is in this sense different.

The last set of mental maps represents the areas where the guides spend their weekly time off, when they get to decide what they want to do. The guide in the first example spends time in the Agia Marina resort area close to where she lives and in the neighbouring city of Chania, where she visits frequently for shopping and to connect with the local life, see Figure 3a. Occasionally she also visits Rethymno to meet her guide friends. The other guide highlighted leisure-time spent in Platanias and Agia Marina (circle with initials VP) dining out and exercising with her friends, whereas her daily movement is concentrated near Chania, see Figure $3 \mathrm{~b}$. These areas are more restricted than the ones for their daily movements, although not exhaustively so. The difference they make in scales is even more clearly seen in relation to the areas they need to know about or discuss with their clients. Their short leisure time makes them evaluate the distances they are able or willing to travel within the limited time available.

The guides characterize themselves as people who have looked to living abroad, are keen travellers, and in addition, like to work with people in customer service. They would like to explore the island more, but they find their limited leisure time filled with necessary everyday chores or relaxing in the same place their clients spend their holidayeveryday. Resorts are seasonal homes that both the guides and their clients share. The guides see that their clients have relatively more freedom in terms of their holiday schedule, but they are able to recognize some limitations in these 'freedoms' as everyone has some restrictions and conditions that might limit their decisions. This relational dialogue between freedom and restriction is the outcome of the processes that have ended in the different posi-

Fig. 3. Two mental maps representing the area of leisure. (Interviews 1 and 2).

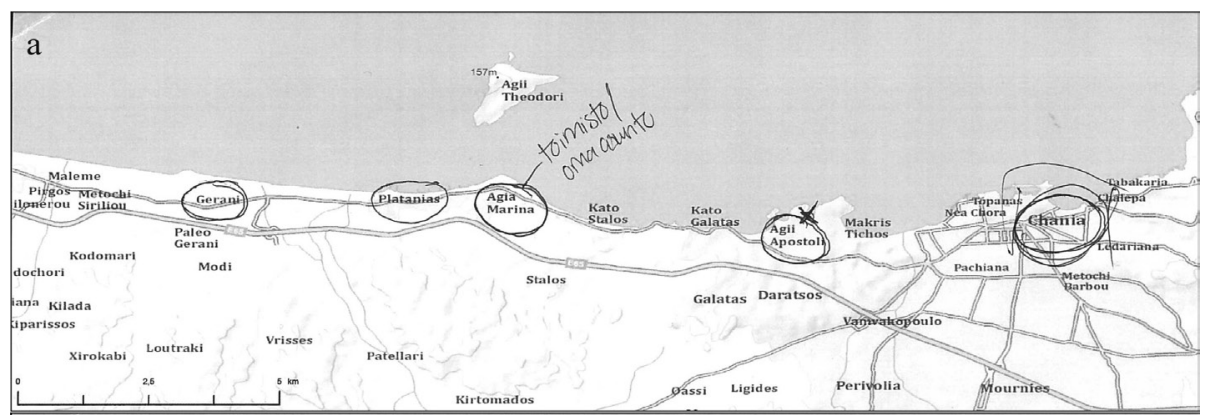

b

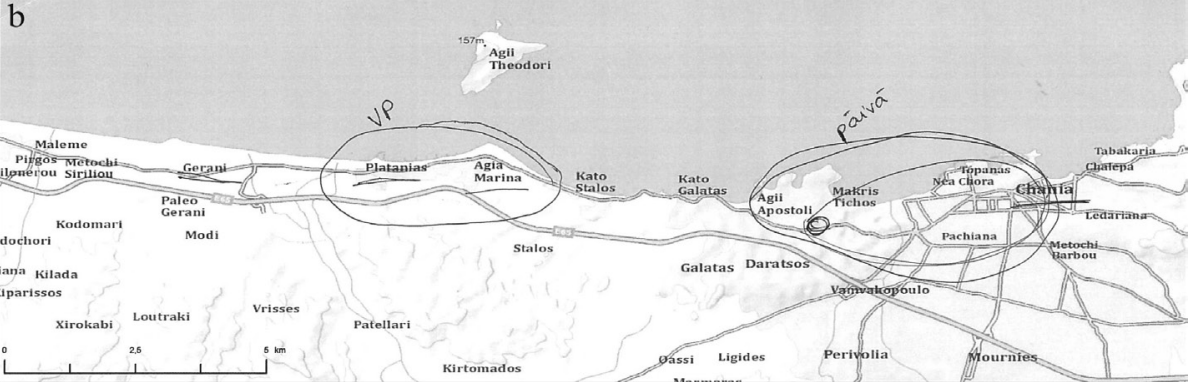


tions the guides and tourists are in: one got the job and the other one got the holiday (Franquesa 2011). So it is not necessarily a negative-positive dichotomy. One guide (Fig. 3a) exemplifies the relationship between her tourist identity and the restrictions of her everyday life in a nutshell:

"I will try to see a bit more this summer [of Crete
than during last summer]... it is nice to go see lo-
cal life once in a while [in Chania]... It is nice to
get out of [the resort] because otherwise they [cli-
ents] come along there on the streets [laughs]. But
often... you just want to stay home and sleep and
[...] do daily chores: doing the laundry [...] stay
on the beach or by the pool" (Interview 1).

In the previous excerpt the guide, however, prefers to avoid clients while on her leisure time because their relationship is coloured by the work context. This does not mean that the presence of tourists or clients were bad per se but in the context of leisure, they prefer not to be doing their work, i.e. being in the role of a guide serving the clients. The closest to travelling that the guides get is when they familiarize themselves with and gather information about the new destination after arriving there.

\section{Constructing intensive and extensive spatiality of mass tourism}

Throughout the interviews, the guides categorize the spatialities of mass tourism into two sets of ideas: intensive and extensive spatiality. These ideas combine their views on their own spatiality as guides and the spatiality of their clients. Intensive spatiality marks the sensuous connection to the place whereas extensive spatiality is based on exploration.

\section{Intensive spatiality of mass tourism}

The guides construct an idea of intensive spatiality by describing mass tourism as an assemblage of "small things" even of everyday quality: using a rather small area, sensuous experience, embodied practices, living in the moment or seizing the moment, sensing the atmosphere of the place, relaxation and spending time with loved ones. It is an inwards looking relationship that is created between the place and the person. The guides frame intensive spatiality as involving those clients who, for example, spend time at the hotel (especially the theme hotel) and who focus on relaxation, being in the sun and sand, spending time with family rather than touring all over the island: "After all people come here to get the sun and they want to lounge around and relax" (Interview 1).

The guides criticize, as seasonal residents, the resorts for not having visibly local everyday life and a categorization is made between those locals working at resorts and those who live and work in the local villages: "These holiday villages that are full of tourists in the summertime [...] the locals who are there, are there mainly for work, so there is not the kind of local everyday-life there" (Interview 8). This highlights the mobile character of these places, where almost nobody stays permanently. Although part of everyday life (seasonal) for locals does take place in the resorts, an idea is given that it would be preferred if their non-workrelated life would be visible as well: as in the villages outside the resorts where people are said to live traditional lives in a setting in which time seems to have stopped and offer sensations of 'pastness' (see Lagerqvist 2013). The seizing the moment effect is based on physical features, but also on the atmosphere that is sensed while in the place. There is a link between intensive and extensive spatiality, and some guides would prefer intensive spatiality to occur after the extensive spatiality: "If you go to those small villages, the atmosphere is totally different [...] the scent that you get there [in the mountain villages]... the air is so different, is fresh there compared to here in Platanias Agia Marina" (Interview 6). The trips from Finland to relaxing Crete and from the tourist resort to the 'stillness' of the local village are however a result of choices which require moving (see Franquesa 2011; Lagerqvist 2013).

The guides also exhibit understanding towards intensive spatiality that stems from the ways the destination is experienced in relation to the shared cultural background. It can be something emotional or sensuous, rather hard to put in words as one guide exemplifies: "Cretan atmosphere. ... that humanity of people... it is somehow so tangible... here people acknowledge you immediately... In Finland you don't get that in the same way from a stranger... also children get noticed" (Interview 9). This refers to the hospitality and cultural features that are appreciated and longed for in relation to the guide's or tourists' own cultural context. It also highlights the power of encounters in creating an atmosphere. And the need of everyone to be ap- 
preciated, not thought of as intruders, as indeed mass tourists are often described to be in various discussions (see Boorstin 1964; Turner \& Ash 1975). The spatial relationship is not only between a person and the place but also evolves between people and their relationships, it is shared and social: both between locals and tourists, and among tourists. Repeat visitors were named as a group of people who have deepened their relationship and overcome temporal restrictions in getting to know a place by returning to the same place several times: "When they have visited the same place several times, they have acquaintances there and maybe even on a level of friendship with some of the locals" (Interview 8). There are social networks that create tourism or keep it going (Larsen et al. 2007). The spatiality of the two groups is articulated through a sense of shared viewpoints and practices. Some of the guides have found ways to experience the resort or create a sense of belonging in a similar manner as perhaps their clients have: "There are several nice cafés in Platanias Square and this café culture has become totally rooted in me. I like to sit there and watch the course of life [...] This Crete is a little like a summer home to $\mathrm{me}^{\prime \prime}$ (Interview 7).

Intensive spatiality is even something to be promoted on some occasions. In the following excerpt, the guide makes a contribution in that vein. An everyday and holiday practices are combined in a theme hotel: "So that we get families to spend quality time together, which they do not necessarily find time for at home, so we try to teach people to spend time as a whole family" (Interview 4). The theme belongs to the wider discussions in Finnish society about the challenges of work and family life. The sociality of tourism is characterized here as something that is also highlighted by the tour operator in creating a product for the contemporary families for the contemporary needs in a holiday context that some are interested in (see Obrador 2012). "A view of mass tourism as alienating takes for granted the inhospitality of the spaces of mass tourism for families" (Obrador 2012: 402). "If it is a family with children, I will not be suggesting for them to go touring the whole island. They cannot bear to be in the car" (Interview 1). This kind of contextual sensitivity is considered to be the key to a successful guide-client relationship, and the knowledge of the guide is always used in relation to the client's context even though their own values may be somewhere else. For instance, holidays are acknowledged as being temporally limited: "Probably they have done a lot of work during that year and when they go for a holiday, they just want to relax" (Interview 8). People are making decisions regarding travelling and places they visit with various motivations in dialogue with their needs and wants: "They ask which are the good restaurants and are there grocery shops, cashpoints, pharmacies, doctors and issues like this that are linked to their own security and running of their holiday because it is everyday life for that one-week-holiday" (Interview 2). This refers to the resort as a holiday home for tourists, resembling a form of cottage culture (see Lagerqvist 2013; Hiltunen \& Rehunen 2014).

\section{Extensive spatiality of mass tourism}

By extensive spatiality, that is perhaps more outwardly oriented than intensive spatiality, the guides highlight the character of tourism as a movement between the places and "work of tourists": using a larger area, getting to know new places and people. Guides reveal their own values and adopted as well as learnt ideologies in relation to wider discourses about travelling and holidaying (see McCabe 2005) by wishing for certain kinds of practices from their clients: exploring the locale. For one guide, the meaning of Crete is only found outside the coastal resort: "I usually highlight to clients that they should go explore the island and that you get a whole different perception of the whole place when you really [...] go to places that are not necessarily the most touristic ones" (Interview 6). In this role, she is encouraging and teaching clients from her professional, educated perspective. She is also making a hierarchical distinction between the touristic places and the 'local' places and suggests that even inside the tourism phenomenon the touristic places would not be "in place". Another guide exemplifies: "A couple of great guys were here with undefined accommodation for two weeks. They came to tell that they will not be using the room other than for three days and that they have rented a car for ten days and they do not know where they will be going" (Interview 5). In this way, the guides express sharing similar attitudes and values with certain clients, such as independent tourists, who take risks and are adventurous. They also acknowledge elsewhere that certain spatial practices are not possible for all due to the different restrictions and personal preferences.

The guides link extensive spatiality to both the spatial practice and mental attitude: "At Easter people were not satisfied with just knowing where the 
church was but they wanted to know what happens inside" (Interview 4). The interest in the local issues is growing among their clients and already common in Finnish mass tourism: "They ask directly where they can find a really fully Cretan [restaurant]... whose owner has a little farm where all the food comes from. Those are very popular here" (Interview 6). In Finland organic and local food has been trendy discussion topics in recent years but in Crete this has been a rather daily practice. The neighbouring city of Chania is often asked about and visited. The relationship between Chania and the resort area is symbiotic in the guides' talk. Other places frequently mentioned are Cretan villages, beaches, or heritage or natural sites. Some do it by themselves and some ask guides for advice or use guided excursions. The hybrid character of contemporary mass package tourism is present in the interviews as mixed travel motivations: "A little bit in the middle of nowhere this our place [theme hotel], it is a quiet area and near the beach so people very much want to go from there" (Interview 5). The thematic all-inclusive hotel is seen to provide something but not necessarily all, and therefore, there is also movement outside it if people want to experience something else.

The guides evaluate that the strengths of Crete lie in the possibilities for both intensive and extensive spatialities that it offers for different groups of tourists, and this highlights the heterogeneousness within mass tourism and the place as actively speaking to visitors: "Crete is a sufficiently large enough island, diverse enough, that people like to move around [...] These independent travellers are, by the way, also a big group, who rather do by themselves and go by bus and before anything walk" (Interview 10). In this sense, the importance lies in the relationship between a person and the destination and how well they complement each other. The place, the path to reach it and activities carried out are all considered important in the spatiality of mass tourism.

\section{Concluding remarks}

The concept mass tourism destination brings often to mind a named spatial entity, such as Platanias, Benidorm or Playa del Inglés, that are specialized from their surroundings as tourism infrastructures that attract a large number of tourists. Transformations in global tourism, the growing tourist flows, better connections and changes in tourist con- sumption and production present challenges for the mass tourism destination as a category of analysis. In addition to more general approaches, tourism research should pay attention to various experiences of and user perspectives that re-negotiate wider discourses, to the spatialities of mass tourism destinations. In this research, the spatial framing of the mass tourism destination was left open by addressing it as an agglomeration of different spatialities through situated knowledge.

The interview design with the questions of the guides' own spatiality and their clients' spatiality gave more insight into how spatialities are interpreted. Mass tourism practices are evaluated at an ideological level that contains the ideas of 'right' tourism or vacationing (see also McCabe 2005). However, the level of practice is highlighted frequently as challenging the ideology. The suitable decisions are made in specific contexts. For example, lounging on the beach was considered an unappreciated way of holidaying/travelling, as well as a necessary act or understandably desired act in the case of some tourists, and in their own case something constrained by the current situation but still needed (even enjoyed), or something they also like in their own holidays. The interviews conformed to an idea that individuals have intersecting and overlapping, yet different, versions of mass tourism destinations. Social groups, the phases of life, previous experiences of other destinations and the overall relationship to travelling need all to be addressed when analysing mass tourism destinations as collective constructs or as "fields of encounter" of different interests. The conceptualization of mass tourism destinations should underline user perspectives and that everyone encounters the locale and constructs it into a place in their own way (see Wright 2002, and especially Relph 2000). Thus more sensitive interpretation could be created than what the categorization "mass tourists" may suggest.

The results indicate that the 'professionality' and 'knowledge' of mass tourism are not straightforward processes. For example, repeat tourist who has been to the destination several times during several decades was described as possessing a great deal of existential knowledge about the destination compared with a new young guide working in the destination for the first time. In addition to the momentary (event) character of destination knowledge, there are personal or collective preferences in it. Guides are not present in the destination selection or in the whole tourist experience of 
the client. In this regard, the different experiential knowledges would be important to study further in order to contribute to the better academic theorization of mass tourism. In this study, I did not try to interpret the interviewees' responses in relation to certain academic ideals of travelling but rather seek how guides positioned themselves in regard to different spatialities.

The findings conform to the idea that as an analytical category, mass tourism should not be locked in any specific kind of spatiality or place from the 'tourist' (country of origin) point of view, not for the guides' "working destination" nor for their views of their clients' spatiality. The interactivity of the guides' work, which is influenced by the tour operator and the clients, leads to different physical and mental spatial framings. There is no straightforward way to frame mass tourism destination that would adequately cover mass tourism, rather the fragments that construct it. Sun-and-sand seems an easy explanation for motivations and resort for its spatiality but according to interviews, they are only façades behind which more complex collective relationships develop recognizing both enclavic and heterogeneous tourist spaces (Edensor 2001). Intensive spatiality highlighting sensuous experiencing and stillness and extensive spatiality indicating movement and exploration were seen to stem from the same flow of people, but taking place in various locations. The recognized spatialities thus frame the mass tourism destination in the talk of the guides. Places and spatial practices are made meaningful through their relationship. The interplay between these spatialities reflects the combinations of "the destination" that tourist and guides create in their action.

This study conforms to the idea that mass (package) tourism in Finnish case is seen as a largescale, popular phenomenon that is democratized (different social classes) and mixed (different motivations) and as such it is difficult to generalize. I would call this challenge as "mass effect", which in this case reflects the relationship between the guides and the large numbers of clients which could have led to the confirmation of the myth of a homogeneous mass. The guides do not, however, produce a stereotypical representation of a Finnish tourist, which is possibly a result of their work role as customer servers who need to be able to put themselves into their clients' place. The quantity of clients is rather reflected as dynamic, contextual and scattered groups. The growing independence of tourists in mass tourism suggests that discussion between the macro and micro levels of mass tourism theory is important.

In the guides' talk, the development of mass tourism is twofold. On one hand, there is a growing trend of services in forms of all-inclusive resorts and tour operator-led theme hotels set for intensive spatiality. These developments are understood as a result of the hectic pace of contemporary everyday life. These places respond to the needs of those who need to get to a place in which they are allowed to relax and spend time with their significant ones. On the other hand, there are a growing number of independent tourists that desire to visit new places, know about the everyday practices of local people and use local services, opening possibilities for the resorts and the areas nearby. Both of the developments are seen as responses to contemporary life at home, but local elements can be present in both of the spatialities. Research and discussions between different interest groups, locals and tourists could reveal common agendas and separate desires for the future.

\section{ACKNOWLEDGEMENTS}

I want to thank the anonymous referees for their instructive comments. I also appreciate the helpful comments of Jarkko Saarinen, Joni Vainikka, Eva Kaján, Kaarina Tervo-Kankare and Maaria Niskala. I want to show my gratitude for the co-operation for Anna Salmi, Janne Ohralahti and Maria Widell (Aurinkomatkat) and Kari Henner and Liselotte Hyllendahl (Finnmatkat/TUI). And of course, all the interviewees: thank you for giving your precious time. A previous draft was presented at the Annual Conference of ATLAS 2013 in Malta. The fieldwork for this study was supported by the Union of Finland Greece associations (Suomi-Kreikka yhdistysten liitto ry) with a grant from the Arvo Allonen memory fund (Arvo Allosen muistorahasto) and by the Department of Geography, University of Oulu.

\section{REFERENCES}

AFTA 2014. Lentäen tehdyt vapaa-ajan valmismatkat sisältäen räätälöidyt matkapaketit. $<w w w$. smal.fi/index.php?361> 28.01.2014.

Agarwal S 2012. Relational spatiality and resort restructuring. Annals of Tourism Research 39: 1, 134-154. http://dx.doi.org/10.1016/j.annals.2011.05.007.

Andrews H 2011. The British on holiday. Charter tourism, identity and consumption. Channel View, Bristol.

Andriotis K 2011. A comparative study of visitors to urban, coastal and rural areas. Evidence from the 
island of Crete. European Journal of Tourism Research 4: 2, 93-108.

Anton Clavé S 2012. Rethinking mass tourism, space and place. In Wilson J (ed). Routledge handbook of tourism geographies, 217-224. Routledge, London.

Apostolakis A 2013. Individuals' perceptions for natural resources: the case of Cretan beaches. Anatolia 25: 1, 117-130.

http://dx.doi.org/10.1080/13032917.2013.838689.

Aquiló E, Alegre J \& Sard M 2005. The persistence of the sun and sand tourism model. Tourism Management 26: 2, 219-231.

http://dx.doi.org/10.1016/j.tourman.2003.11.004.

Ashworth G \& Voogd H 1990. Can places be sold for tourism? In Ashworth G \& Goodall B (eds). Marketing tourism places, 1-16. Routledge, London.

Berger P \& Luckmann T 1967. The social construction of reality. Doubleday, New York.

Bitner MJ 1992. Servicescapes: the impact of physical surroundings on customers and employees. Journal of Marketing 56: 2, 57-71.

http://dx.doi.org/10.2307/1252042.

Boorstin D 1964. The Image. Harper \& Row, New York.

Bourdieu P 1984. Distinction. A social critique of the judgement of taste. Routledge \& Kegan Paul, London.

Bramwell B 2004. Mass tourism, diversification and sustainability in Southern Europe's coastal regions. In Bramwell B (ed). Coastal mass tourism, 1-31. Channel View, Clevedon.

Brey TE, Morrison AM \& Mills JE 2007. An examination of destination resort research. Current Issues in Tourism 10: 5, 415-442. http://dx.doi.org/10.2167/cit315.0.

Brubaker R \& Cooper F 2000. Beyond 'identity'. Theory and Society 29: 1, 1-47. http://dx.doi.org/10.1023/A:1007068714468.

Burr V 1995. An introduction to social constructionism. Routledge, London.

Butler RW 1980. The concept of a tourist area cycle of evolution: Implications for management of resources. The Canadian Geographer 24: 1, 5-12. http://dx.doi.org/10.1111/j.1541-0064.1980.tb00970.x.

Casey ME 2010. Low cost air travel: Welcome aboard? Tourist Studies 10: 2, 175-191. http://dx.doi.org/10.1177/1468797611403061.

Cheong S-M \& Miller ML 2000. Power and tourism. A Foucauldian observation. Annals of Tourism Research 27: 2, 371-390. http://dx.doi.org/10.1016/S0160-7383(99)00065-1.

Crick M 1989. Representations of International Tourism in the Social Sciences: Sun, Sex, Sights, Savings, and Servility. Annual Review of Sociology 18, 307-344.

Duval DT 2004. Trends and circumstances in Caribbean tourism. In Duval DT (ed). Tourism in the Caribbean, 3-22. Routledge, London.

Edensor T 2001. Performing tourism, staging tourism: (Re)producing tourist space and practice. Tourist Studies 1: 1, 59-81.http://dx.doi.org/10.1177/146879760100100104.

Finavia 2014. Lentoliikennealan murros jatkuu. Aasian merkitys korostuu. Toimintakertomus 2011.
$<$ https://www.finavia.fi/fi/tiedottaminen/julkaisuarkisto/> 04.11.2014.

Franquesa J 2011. "We've lost our bearings": Place, tourism and the limits of the "mobility turn". Antipode 43: 4, 1012-1033. http://dx.doi.org/10.1111/j.1467-8330.2010.00789.x.

Gmelch G 2003. Behind the smiles: the working lives of Caribbean tourism. Indiana University Press, Bloomington.

Gold P \& White R 1974. Mental maps. Penguin Books, Middlesex.

Hiltunen MJ \& Rehunen A 2014. Second home mobility in Finland: Patterns, practices and relations of leisure oriented mobile lifestyle. Fennia 192: 1, 1-22. http://dx.doi.org/10.11143/8384.

Hottola P 2005. The metaspatialities of control management in tourism: Backpacking in India. Tourism Geographies 7: 1, 1-22. http://dx.doi.org/10.1080/1461668042000324030.

Hottola P 2013. Tourism spaces, behaviours and cultures: The metaspatialities of tourism. In Wilson J (ed). Routledge handbook of tourism geographies, 139-146. Routledge, London.

Ivars i Paidal JA, Rodríguez Sánches I \& Rebollo JFV 2013. The evolution of mass tourism destinations. New approaches beyond deterministic models in Benidorm (Spain). Tourism Management 34, 184-195.

http://dx.doi.org/10.1016/j.tourman.2012.04.009.

Jackson P 1989. Maps of meaning. Unwin Hyman, Boston.

Jacobsen JKS, Skogheim R \& Dann GMS 2014. Sun, sea, sociability, and sightseeing: Mediterranean summer holidaymaking revised. Anatolia. http://dx.doi.org/10.1080/13032917.2014.931288.

Jokinen E \& Veijola S (eds) 2008. Töissä tunturissa. Ajatuksia ja kirjoituksia matkailutyöstä. Lapland University Press, Rovaniemi.

Knox D 2009. Mobile practices and youth tourism. In Obrador Pons P, Crang M \& Travlou P (eds). Cultures of mass tourism. Doing the Mediterranean in the age of banal mobilities, 143-155. Ashgate, Farnham.

Krippendorf J 1987. The holiday makers. Understanding the impact of leisure and travel. ButterworthHeinemann, Oxford.

Lagerqvist M 2013. 'I would much rather be still here and travel in time': The intertwinedness of mobility and stillness in cottage living, Fennia 191: 2, 92105. http://dx.doi.org/10.11143/8287.

Larsen J, Urry J \& Axhausen KW 2007. Networks and tourism. Mobile social life. Annals of Tourism Research 34: 1, 244-262. http://dx.doi.org/10.1016/j.annals.2006.08.002.

Löfgren O 1999. On holiday. A history of vacationing. University of California Press, Berkeley.

Maffesoli M 1996. The time of the tribes. The decline of individualism in mass society. SAGE, London.

Massey D 1994. Space, place and gender. Polity Press, Oxford.

Massey D 2005. For space. SAGE, London.

McCabe S 2005. 'Who is a tourist?': A critical review. Tourist Studies 5: 1, 85-106. http://dx.doi.org/10.1177/1468797605062716. 
McCabe S \& Stokoe H 2004. Place and identity in tourist accounts. Annals of Tourism Research 31: 3, 601-622. http://dx.doi.org/10.1016/j.annals.2004.01.005.

Miller D 1987. Material culture and mass consumption. Blackwell, Oxford.

Miller ML \& Auyong J 1998. Remarks on tourism terminologies: Anti-tourism, mass tourism, and alternative tourism. In Miller ML \& Auyong J (eds). Proceedings of the 1996 world congress on coastal and marine tourism, 1-24. University of Washington, Washington.

Obrador P 2012. The place of the family in tourism research: Domesticity and thick sociality by the pool. Annals of Tourism Research 39: 1, 401-420. http://dx.doi.org/10.1016/j.annals.2011.07.006.

Obrador Pons P, Crang M \& Travlou P 2009. Introduction: Taking Mediterranean tourists seriously. In Obrador Pons P, Crang M \& Travlou P (eds). Cultures of mass tourism. Doing the Mediterranean in the age of banal mobilities, 1-20. Ashgate, Farnham.

Paasi A 2002. Place and region: Regional worlds and words. Progress in Human Geography 26: 6, 802811. http://dx.doi.org/10.1191/0309132502ph404pr.

Poon A 1993. Tourism, technology and competitive strategies. CABI, Oxon.

Pred A 1984. Place as historically contingent process: Structuration and the time-geography of becoming places. Annals of the Association of American Geographers 74: 2, 279-297.

http://dx.doi.org/10.1111/j.1467-8306.1984.tb01453.x.

Rakić T \& Chambers D 2012. Rethinking the consumption of places. Annals of Tourism Research 39: 3, 1612-1633. http://dx.doi.org/10.1016/j.annals.2011.12.003.

Rantala O 2010. Tourist practices in the forest. Annals of Tourism Research 37:1, 249-264. http://dx.doi.org/10.1016/j.annals.2009.09.003.

Relph E 1976. Place and placelessness. Pion Limited, London.

Relph E 2000. Author's response: Place and placelessness in a new context. Progress in Human Geography 254: 4, 617-619. http://dx.doi.org/10.1191/030913200100189139.

Rose G 1997. Situating knowledges: Positionality, reflexivities and other tactics. Progress in Human Geography 21: 3, 305-320. http://dx.doi.org/10.1191/030913297673302122.

Rosselló J \& Riera A 2012. Pricing European package tours: The impact of new distribution channels and low-cost airlines. Tourism Economics 18: 2, 265-279. http://dx.doi.org/10.5367/te.2012.0121.

Räikkönen J \& Honkanen A 2013. Does satisfaction with package tours lead to successful vacation experiences? Journal of Destination Marketing \& Management 2: 2, 108-117.

http://dx.doi.org/10.1016/j.jdmm.2013.03.002.

Saarinen J 2004. 'Destinations in change': The transformation of tourist destinations. Tourist Studies 4: 2, 161-179.

http://dx.doi.org/10.1177/1468797604054381.
Saraniemi S \& Kylänen M 2011. Problematizing the concept of tourism destination: An analysis of different theoretical approaches. Journal of Travel Research 50: 2, 133-143. http://dx.doi.org/10.1177/0047287510362775.

Selänniemi T 2001. Pale skin on Playa del Anywhere: Finnish tourists in the liminoid south. In Smith VL \& Brent M (eds). Hosts and guests revisited: Tourism issues of the 21st century, 80-92. Cognizant, New York.

Shaw G \& Williams AM 2002. Critical issues in tourism. Blackwell, Oxford.

Sheller M \& Urry J 2004. Places to play, places in play. In Sheller M \& Urry J (eds). Tourism mobilities. Places to play, places in play, 1-10. Routledge, London.

Squire SJ 1998. Rewriting languages of geography and tourism. Cultural discourses of destinations, gender and tourism theory in the Canadian Rockies. In Ringer G (ed). Destinations. Cultural landscapes of tourism, 80-100. Routledge, London.

Torres R 2002. Cancun's tourism development from a Fordist spectrum of analysis. Tourist Studies 2: 1, 87116. http://dx.doi.org/10.1177/14697602002001098.

Tribe J 2006. The truth about tourism. Annals of Tourism Research 33: 2, 360-381. http://dx.doi.org/10.1016/j.annals.2005.11.001.

Tuffin K \& Howard C 2001. Demystifying discourse analysis: Theory, method and practice. In McHoul A \& Rapley M (eds). How to analyse talk in institutional settings. A casebook of methods, 196-205. Continuum, London.

Turner L \& Ash J 1975. The golden hordes. International tourism and the pleasure periphery. Constable, London.

Urry J \& Larsen J 2011. The tourist gaze 3.0. SAGE, London.

Vainikka J 2012. Narrative claims on regions: prospecting for spatial identities among social movements in Finland. Social \& Cultural Geography 13: 6, 587-605.

http://dx.doi.org/10.1080/14649365.2012.710912.

Vainikka V 2013. Rethinking mass tourism. Tourist Studies 13: 3, 268-286. http://dx.doi.org/10.1177/1468797613498163.

Wheeller B 2003. Alternative tourism - A deceptive ploy. In Cooper C (ed). Classic reviews in tourism, 227-234. Channel View, Clevedon.

Wright S 2002. Sun, sea, sand and self-expression: mass tourism as an individual experience. In Berghoff H, Korte B, Schneider R \& Harvie C (eds). The making of modern tourism, 181-202. Palgrave, Basingstoke.

Young M 1999. The social construction of tourist places. Australian Geographer 30: 3, 373-389. http://dx.doi.org/10.1080/00049189993648. 